\title{
"ABENOMIKA" W OBLICZU WYZWAŃ DLA BEZPIECZEŃSTWA EKONOMICZNEGO JAPONII
}

\author{
"Abenomics" in the face of challenges for Japan's economic security
}

Streszczenie: Głównym celem artykułu jest ogólna ocena polityki gospodarczej rządu premiera Shinzo Abe w latach 2012-2020. Zaprezentowano obecna sytuacje ekonomiczno-spoteczna w Japonii, z pogtębiona analiza wybranych przez autora elementów. Ostatniq część artykułu stanowi studium przypadku, w którym przedstawiono główne zatożenia „abenomiki" i omówiono jej skuteczność w oparciu o wskaźniki ekonomiczne. Dziatania podejmowane w ramach prowadzonej polityki monetarnej i fiskalnej byly niewystarczające. Polityka "trzech strzał" nie przyniosła zamierzonych efektów głównie przez zaniechania na polu reform strukturalnych i dostosowywanie decyzji do kalendarza wydarzeń politycznych.

Słowa kluczowe: Japonia, Abenomika, bezpieczeństwo ekonomiczne, stagnacja, Shinzo Abe, gospodarka, ekonomia, gospodarka bańki mydlanej, polityka, Bank Japonii

Abstract: The main aims of the article are to provide a general assessment of the economic policy of Prime Minister Shinzo Abe's government in 2012-2020. The current economic and social situation in Japan is presented with an in-depth analysis of the elements selected by the author. The last part of the article is a case study - the main assumptions of "abenomics" are presented, and its effectiveness based on economic indicators is discussed. Actions taken as part of the pursued monetary and fiscal policy were insufficient. The "three arrows" policy did not bring the expected results mainly due to the neglect of structural reforms and the adjustment of decisions to the calendar of political events.

Keywords: Japan, Abenomics, economic security, stagnation, Shinzo Abe, economy, economy, economic bubble, politics, Bank of Japan

1 Student II roku stosunków międzynarodowych, specjalizacja: gospodarka i biznes międzynarodowy, Uniwersytet Wrocławski, email: michalak.patrycjusz@gmail.com, ORCID: 0000-0002-4140-4859. 


\section{Wprowadzenie}

Od lat 90. XX wieku w Japonii mówi się o „trzech straconych dekadach". Moment pęknięcia bańki spekulacyjnej był druzgocący w efektach dla gospodarki tego państwa. To wtedy właśnie okazało się, na jak kruchych fundamentach powstała cała potęga gospodarcza kraju. Wraz z gospodarczą stagnacją przyszło wiele zmian społecznych - Japonia zmaga się z licznymi problemami, a kolejne rządy nie potrafią znaleźć skutecznego ich rozwiązania. Starzejące się społeczeństwo, nierówności społeczne, dyskryminacja kobiet na rynku pracy - to jedynie kilka kwestii, które wymagają szybkiego i skutecznego działania rządzących. Japonia stała się popularnym "przykładem ostrzegawczym” dla innych państw. Japońskie zmagania z gospodarczą rzeczywistością były powodem, dla którego cały świat zaczął zastanawiać się nad zintensyfikowaniem polityki stymulacyjnej. Wśród ekspertów pojawiła się dyskusja o potrzebie większej aktywności banków centralnych - Rezerwa Federalna oraz inne banki rozpoczęły proces drukowania pieniędzy w celu uniknięcia spadku cen. Podążając za bardzo popularną ekonomią zapoczątkowaną przez Johna Maynarda Keynesa, japońskie władze uchwalały potężne programy stymulacyjne w przeciągu zaledwie dziesięciu lat (od 1990-2000 r.) Japonia wydała na rządowe programy ponad sto bilionów jenów.

W ramach coraz szerzej rozumianego bezpieczeństwa ekonomicznego Kraj Kwitnącej Wiśni ma do rozwiązania szereg spraw w zakresie realizowanej polityki społecznej. Japonia wciąż pozostaje trzecią potęgą gospodarczą na świecie, którą wraz ze zmianami gospodarczymi czeka wiele przemian.

Celem artykułu jest ogólna ocena polityki gospodarczej najdłużej urzędującego premiera Japonii Shinzo Abe i odpowiedź na pytanie o efektywność realizowanej strategii gospodarczej w latach 2012-2020. Tytułowa „abenomika” była pierwszym spójnym programem gospodarczo-społecznym zaproponowanym Japończykom od lat 90 . XX w. W artykule zostały przedstawione instytucjonalne przyczyny trwającej stagnacji gospodarczej. Omówiono również wybrane problemy, a kryterium ich wyboru stanowiła przede wszystkim ocena autora o ich kluczowości oparta na przeglądzie literatury tematycznej. Starano się wykazać, że aktywizacja kobiet na rynku pracy i reformy systemu opieki społecznej są najpoważniejszymi wyzwaniami dla japońskiego rządu. Główną hipotezą opracowania jest twierdzenie, że najważniejsze kryterium sukcesu „abenomiki” 
to powodzenie w realizacji "trzeciej strzały", czyli w reformach strukturalnych.

Kluczową metodą użytą $\mathrm{w}$ artykule jest analiza literatury przedmiotu i materiałów źródłowych dotyczących współczesnej gospodarki Japonii oraz analiza informacji i danych makroekonomicznych zawartych w raportach organizacji międzynarodowych, takich jak Bank Światowy, Międzynarodowy Fundusz Walutowy i Światowa Organizacja Handlu. Ważną część opracowania stanowiła analiza artykułów w japońskich portalach informacyjnych prowadzonych w języku angielskim, w szczególności działów dotyczących gospodarki. Zagadnienie bezpieczeństwa ekonomicznego wymaga podejścia interdyscyplinarnego, łączącego w sobie perspektywę zarówno nauk ekonomicznych, jak i socjologii oraz nauk o polityce. Biorąc pod uwagę potrzebę zrozumienia czynników, które mają wpływ na sytuację społeczno-gospodarczą w Japonii, przyjęto podejście interpretatywne.

\section{Instytucjonalne uwarunkowania gospodarczej stagnacji}

Wydłużająca się stagnacja gospodarcza zmusiła kolejne rządy do podejmowania działań makroekonomicznych, które miały pobudzić gospodarkę. Nie przyniosły jednak oczekiwanych efektów. Najważniejszymi decyzjami w ramach walki z recesją były projekty robót publicznych, na które przeznaczano bardzo dużą część wydatków budżetowych. W ciągu 10 lat był to 1 bln USD (Potocka, Pietrasiak 2004: 102-104).Cięcia podatkowe, polityka obniżania nominalnej stopy procentowanej lub zwiększenie bazy monetarnej poprzez coroczną wzmożoną emisję obligacji rządowych również nie wpłynęły na ożywienie koniunktury. W 2001 r. deficyt budżetowy sięgał 10\% PNB, zadłużenie państwa 120\% PNB, a wciąż rosnące bezrobocie sięgało 5,4\%. Tempo rozwoju gospodarczego oscylowało wokół zera (Potocka, Pietrasiak 2004: 102-104).

Na nieefektywność w sektorze finansowym duży wpływ miały fatalne rozwiązania instytucjonalne. Rząd wielokrotnie stosował „praktykę konwoju". W trakcie zamykania (proces ten trwał ponad pół roku) czwartej największej firmy maklerskiej Yamaichi Securities pracownicy otrzymywali wynagrodzenie w postaci pożyczek z Banku Japonii. Ministerstwo Finansów stosowało wiele zabiegów, mających na celu przedłużenie 
życia przedsiębiorstw, nad którymi wisiało widmo bankructwa. Przeprowadzano fuzje ze zdrowymi podmiotami, częściowe transfery majątku, zastrzyki finansowe $\mathrm{w}$ postaci publicznych pieniędzy i nawet czasowo nacjonalizowano spółki (Młodawska 2003: 60).

Struktura japońskich keiretsu, a konkretnie system wzajemnej własności akcji stanowił jeden z istotnych czynników kryzysu. Mechanizm własności wewnątrzgrupowej oddawał ogromną część władzy w ręce niewielkiej grupy akcjonariuszy. Korzystali oni z kredytów bankowych, nie chcąc zdawać się na niepewne mechanizmy giełdowe. Unikano $\mathrm{w}$ ten sposób sytuacji, w której pojawiliby się silni zewnętrzni akcjonariusze, którzy w razie braku rentowności zwolniliby zarząd lub zaczęliby wymagać specjalistycznych kwalifikacji.

Problemem japońskiej rzeczywistości gospodarczej były (i nadal są) zbyt bliskie kontakty pomiędzy urzędnikami bankowymi i przedsiębiorstwami na tle pozyskiwania profesjonalnych informacji z sektora przedsiębiorstw przemysłowych. Niepisana zasada utrzymywania przez banki akcji w przedsiębiorstwach i przedsiębiorstw w tych samych bankach była nagminną praktyką. Miało to olbrzymi wpływ na stabilność całego systemu. W sytuacji problemów finansowych jednego z podmiotów pojawiała się groźba braku płynności w całym łańcuchu banki-przedsiębiorstwa.

W aspekcie strukturalnym warto wspomnieć o relacjach między rządem a sektorem prywatnym. Specyfika tych stosunków jest wymieniana jako jedna z przyczyn dzisiejszych problemów japońskiej gospodarki. Wbrew obiegowej opinii, wedle której władze w sposób szczególny premiowały i dofinansowywały sektor przemysłu wysokich technologii, to właśnie schyłkowe gałęzie przemysłu (górnictwo, energetyka lub przemysł włókienniczy) uzyskały największą pomoc. Panowała powszechna tolerancja dla nierentownych przedsiębiorstw w niewydajnych działach przemysłu i usługach około przemysłowych. Instytucje finansowe $\mathrm{z}$ dużymi nadwyżkami budżetowymi w okresie prosperity zaczęły udzielać kredytów i pożyczek bez odpowiedniej kalkulacji ryzyka inwestycyjnego. W oparciu o czynniki krótkookresowe przyczyniło się to do jeszcze większej stymulacji gospodarczej, jednak w perspektywie długookresowej było jedną z przyczyn wychodzenia potencjału gospodarczego Japonii poza ramy samokontroli rynkowej. „Przegrzanie gospodarki” i zbyt późna reakcja władz doprowadziły do pęknięcia mechanizmu spekulacyjnego, który obnażył wszystkie słabości drugiej (w opisywanym okresie) gospodarki świata. 
Załamanie gospodarcze w Japonii nastąpiło w sytuacji zrównoważonych finansów publicznych, ostrożnej polityki płacowej, braku chronicznych deficytów i bezrobocia. Szczególną rolę odegrały jednak banki, nadmierne ryzyko podejmowane przez instytucje finansowe i przedsiębiorstwa. Nieostrożna polityka udzielania kredytów po stronie banków, niepewne inwestycje o niskiej efektywności finansowane z kredytów po stronie przedsiębiorców, praktyczny brak nadzoru bankowego i słabe regulacje prawne zachęcały do podejmowania nieprzemyślanych decyzji. Wyjątkowa struktura gospodarki japońskiej doprowadziła do sytuacji, w której wyłącznie wielkie przedsiębiorstwa generowały zyski, a małe i średnie przynosiły straty.

\section{Omówienie głównych problemów ekonomiczno-społecznych w Japonii}

Japonia jest państwem o licznych problemach ekonomicznych i społecznych. W latach 70 i 80 . XX w. o Japończykach można było powiedzieć, że niemal $w$ większości stanowili klasę średnią. Ich zamożność wynikała z koniunktury gospodarczej, ale i z dominacji w strukturze gospodarczej klasycznego przemysłu ciężkiego, który zatrudniał na szeroką skalę rzeszę ludzi. Duża rola związków zawodowych, którym nadano szereg praw, stanowiła przyczynę stopniowego wzrostu płac w zakładach przemysłowych. Sytuacja diametralnie zmieniła się, gdy sztucznie rozpędzona gospodarka wpadła w kryzys, a następnie w wieloletnią stagnację. Dzisiaj społeczeństwo japońskie jest społeczeństwem wielu nierówności społecznych i biedy. Wskaźnik ubóstwa sięga niemal 15\% populacji (w szczególności wśród osób starszych i dzieci). Złe perspektywy demograficzne, wedle których do $2050 \mathrm{r}$. populacja kraju zmniejszy się z obecnych $127 \mathrm{mln}$ do $100 \mathrm{mln}$, są tylko jednym z wielu powodów do zmartwień. XX w. to czas stale rosnącej populacji - z 44 mln w 1900 do 128 mln w $2000 \mathrm{r}$. W połowie lat 70. XX w. jedna Japonka posiadała statystycznie 2,1 dzieci, obecnie wskaźnik ten wynosi 1,4. W 2016 r. po raz pierwszy od 117 lat liczba urodzeń nie przekroczyła miliona (wyniosła ok. 980 tys.), podczas gdy liczba zgonów osiągnęła poziom 1,3 mln (Grabowiecki 2000: 66-70). Rok 2019 był najgorszy pod względem liczby urodzeń od momentu, kiedy kraj zaczął prowadzić statystyki (1899 r.) - urodziło się zaledwie 865239 dzieci. 
Niemal do samego końca ostatniej dekady XX w. miał miejsce stały przyrost ludzi młodych, którzy zasilali chłonny rynek pracy. Osiągnięto rekordowy wskaźnik $67 \mathrm{mln}$ pracowników. Prognozy na najbliższe stulecie są dla Japonii bardzo niekorzystne - już w połowie XXI w. liczba pracowników zmaleje do 42 mln (Grabowiecki 2005: 68). Jeżeli Japonia nie znajdzie skuteczniej recepty na odwrócenie negatywnego trendu demograficznego, to sytuacja na rynku pracy będzie bardzo zła. Rozwiązaniem może okazać się zmiana $\mathrm{w}$ podejściu do polityki imigracyjnej - złagodzenie przepisów i otwarcie granic dla obcokrajowców. Przyczyną złych perspektyw jest zarówno spadek liczby urodzeń, jak i bardzo szybkie starzenie się japońskiego społeczeństwa. Obecnie Kraj Kwitnącej Wiśni często nazywany jest „Krajem Usychającej Wiśni” lub „krajem seniorów”. Starzenie się społeczeństwa jest naturalnym procesem państwach o wysokim poziomie rozwoju gospodarczego i społecznego. Powinno to jednak wymuszać na rządach aktywną politykę gospodarczą w celu odwrócenia niekorzystnych tendencji. O „starzejącym się" społeczeństwie mówi się w sytuacji, w której co najmniej 7\% ludności stanowią seniorzy - Japonia wysuwa się dalece naprzód, ponieważ w 2017 r. stanowili oni 27,7\% populacji (35,2 mln) (Gerlach 1992: 174). Odsetek ludzi starszych jest największy wśród siedmiu najbardziej uprzemysłowionych krajów świata² Jest to ogromne wyzwanie dla systemu emerytalnego, którego główne założenia, filary oraz wydolność zostanie opisana w dalszej części pracy.

Japonia boryka się z dyskryminacją kobiet na rynku pracy - jest liderem w tej dziedzinie pośród krajów wysoko rozwiniętych. Japonki zarabiają średnio $26 \%$ mniej niż mężczyźni na tych samych stanowiskach (Ząbkowicz 2007: 78-83). Są jednymi z lepiej wykształconych kobiet na świecie - blisko połowa z nich posiada wykształcenie wyższe. Mimo tego często porzucają pracę na rzecz opieki nad dziećmi i domem. Pogodzenie życia zawodowego i rodzinnego jest w Japonii niemal niemożliwe. Specyfika japońskiej rzeczywistości zawodowej: długiego dnia pracy, braku regulacji prawnych umożliwiających branie kobietom urlopów macierzyńskich i wychowawczych, niedostateczna liczba przedszkoli, żłobków czy opiekunek jest czynnikiem blokującym sprawny powrót kobiet do pracy.

2 Najbardziej uprzemysłowionymi krajami świata nazywa się te o największej wartości produkcji przemysłowej. Do siedmiu najbardziej uprzemysłowionych krajów na świecie zalicza się: Chiny, Stany Zjednoczone, Japonię, Niemcy, Koreę Południową, Włochy i Indie. 
W obliczu problemów gospodarczych i demograficznych rząd powinien podjąć odważne kroki w celu aktywizacji tej grupy zawodowej (Ząbkowicz 2007: 78-83).

\subsection{System emerytalny w Japonii}

Wiek emerytalny w Japonii wynosi 60 lat, chociaż władze zachęcają, aby przechodzić na emeryturę dopiero w wieku 65 lat. Japończycy są najdłużej żyjącym narodem na świecie (83,7 lat), a dla gospodarki pogrążonej w wieloletniej stagnacji każda możliwość odciążenia systemu emerytalnego i opóźnienia wypłaty świadczeń jest atrakcyjna. W maju 2020 r. parlament japoński uchwalił prawo, które zezwala, aby pracownik mógł przejść na emeryturę nawet $\mathrm{w}$ wieku 75 lat. To wszystko ma na celu zachęcenie go, by pozostał jak najdłużej aktywny. W 1975 r. statystycznie na 100 osób w wieku pracującym przypadało 13 osób w wieku 65 lat lub wyższym; w 2015 r. było to 46 osób; szacuje się, że do 2050 r. będzie to już 78 osób. Stopa zastąpienia w ujęciu netto wynosi $40 \%$ ostatnich zarobków. Japoński system emerytalny składa się z dwóch filarów. Pierwszym z nich jest filar podstawowy - Kokumin Nenkin. System oparty jest na składkach w stałej wysokości (w 2018 r. było to 160,3 tys. jenów, czyli mniej więcej 500 zł). Obejmuje wszystkich od 20. do 59. roku życia. Pozostała część, czyli zarówno osoby starsze, jak i pracujące zagranicą mogą się do niego dobrowolnie dopisać. Wedle wyliczeń maksymalną emeryturę, jaką otrzyma osoba płacąca składki przez 40 lat, to 779,3 tys. jenów ok. 2 tys. zł miesięcznie (Kiermacz 2018).

Drugi filar adresowany jest dla pracowników etatowych i składa się z pięciu programów pracowniczych, zależnych od wysokości wynagrodzenia. Pracownik sektora prywatnego należy do programu Kosei Nenkin, a pracownik budżetówki do jednego z czterech programów Kyosai Nenkin. Polegają one na odprowadzaniu składek do pewnej wysokości swojego wynagrodzenia - 17,35\% miesięcznej pensji brutto. Ciężar opłacania składek rozkładany jest $\mathrm{w}$ stopniu równym pomiędzy pracownikiem a pracodawcą. Pracownicy na etacie otrzymują emeryturę z dwóch filarów, czyli podstawowego oraz jednego z powyższych (Kiermacz 2018).

W 1964 r. wartość wydatków na utrzymanie systemu zabezpieczenia społecznego wynosiła 5,6\% dochodu narodowego, w tym wartość wydatków na emerytury stanowiła 1,27\% wartości tego dochodu (Pieliński 2012: 6). W 1975 r. wskaźniki te wynosiły odpowiednio 9,49\% i 3,13\%, 
w 1985 r. - 13,69\% i 6,48\%, w 1995 r. - 17,54\% i 9,08\%, w 2000 r. - 21,01\% i 11,08, zaś w 2008 r. - 26,76\% i 14,09\%. Widać, że wydatki na opiekę społeczną stale rosną, a prognozy demograficzne nie wskazują na zmianę tego trendu (Ząbkowicz 2007: 80-82).

\subsection{Kobiety na rynku pracy}

Rola kobiet na rynku pracy oraz ogólniej w japońskiej przestrzeni publicznej jest ściśle związana z kulturą tego kraju. Obraz kobiety jako żony i matki, który do dzisiaj tak silnie funkcjonuje w Japonii, jest pokłosiem lat feudalizmu panującego w kraju. Kobieta wychowująca dziecko jest postrzegana jako „element” poza systemem społecznym. Nie dokłada się do domowego budżetu, więc nie powinna być traktowana na równi z pracującym mężczyzną. Badania przeprowadzane w latach 70. pokazywały, że 40 \% mężczyzn uważało, że kobieta po wyjściu za mąż nie powinna pracować. Statystycznie Japonki porzucają pracę w wieku 25 lat - po wyjściu za mąż lub urodzeniu dziecka. Efektem jest sceptycyzm pracodawców i niechęć do inwestowania w pracownika, który i tak zaraz odejdzie z firmy. Kobiety nie są wysyłane na szkolenia i kursy, a delegowane raczej do prostych czynności biurowych. Jedynie ok. 10\% Japonek po ślubie pozostaje w pracy, odkładając decyzję o dziecku na bliżej nieokreśloną przyszłość. Stanowiska kierownicze zajmują niezwykle rzadko. Chociaż od lat 60. Japonki są coraz lepiej wykształcone (wskaźnik wynosił: 2,5\% w 1960 r., 27\% w 1997 r., 46,7\% w 2015 r., 50,04\% w 2019 r.) to pod naporem społecznych stereotypów porzucają swoją karierę zawodową. Powrót na rynek pracy po okresie urlopu macierzyńskiego jest bardzo trudny - jedyną szansą staje się praca na niepełny etat, bez możliwości awansu i kariery (Marszałek-Kawa, Bodio 2017: 35-37).

Według badań Midori Otake, profesora Uniwersytetu w Tokio, kobiety w Japonii wykonują 50,6\% pracy (opłaconej i nieopłaconej), a otrzymują jedynie 15\% krajowego dochodu. Według danych z $2001 \mathrm{r}$. średnia pensja kobiety z wykształceniem średnim wynosiła 208 tys. jenów (z wyższym 277 tys. jenów), podczas gdy średnia pensja mężczyzny wynosiła odpowiednio 313 tys. jenów (z wyższym 404 tys. jenów), czyli 1,5 razy więcej niż kobiety (Marszałek-Kawa, Bodio 2017: 35-37).

Wzrost udziału kobiet na japońskim rynku pracy to efekt kryzysu gospodarczego i demograficznego. Firmy w ramach cięcia kosztów zwalniały mężczyzn i zatrudniały kobiety. Społeczna akceptacja dla niższego 
wynagrodzenia kobiet stała się częścią wewnętrznej polityki optymalizacji kosztów. Brak rąk do pracy w sektorach dla mniej wykwalifikowanego personelu (gastronomia, proste usługi, opieka nad seniorami) stworzył szansę dla kobiet chcących pracować.

Japoński rząd od 2003 r. był chwalony za projekty mające za zadanie zaaktywizować kobiety na rynku pracy. Junichiro Koizumi wyznaczył za cel osiągnięcie 30\% partycypacji kobiet do 2020 r. na najważniejszych stanowiskach. Premier Shinzo Abe przedstawiając swój program dla gospodarki, słynną „abenomikę”, jako jedno z ważniejszych zadań uczynił polepszenie warunków kobiet i ich możliwości na rynku pracy. Wskaźnik 30\% okazał się jednak nierealny w japońskich warunkach, więc w 2015 r. Biuro ds. Równości płci zredukowało cel do 7\% (Kobiety w zarzadach firm 2020). Japońskie Ministerstwo Pracy wielokrotnie deklarowało wsparcie dla firm, które wyrażą chęć zwiększenia udziału kobiet w zarządach. Wszystkie starania spełzły na niczym, a wielu dyrektorów bardzo sceptycznie wypowiadało się o pomysłach i programach rządu.

\section{Recepta na problemy japońskiej gospodarki - „Abenomika" - założenia polityki rządu Shinzo Abe}

"Abenomika" to publicystyczna nazwa polityki gospodarczej prowadzonej przez gabinet byłego premiera Japonii - Shinzo Abe. W swojej nazwie na myśl przywodzi „reaganomikę”, czyli podażową politykę amerykańskiego prezydenta Ronalda Reagana, realizowaną $\mathrm{w}$ latach 80. XX w. W praktyce jest to jednak połączenie keynesowskiego modelu wsparcia gospodarki z ekonomią podażową (czerpiącą z ekonomii klasycznej). Shinzo Abe chciał zastosować klasyczne metody keynesowskiego modelu gospodarczego: luzowanie ilościowe w polityce monetarnej i stymulację fiskalną. Za sprawą wydatków rządowych do gospodarki miał popłynąć strumień pieniędzy, pobudzając ją. Za cenę ożywienia gospodarczego rząd dopuścił możliwość wzrostu deficytu.

Ożywienie gospodarki i wyjście z okresu deflacji oraz wysokiego kursu jena to główne cele „abenomiki”. Wygrane przez Partię Liberalno-Demokratyczną wybory w grudniu 2012 r. sprawiły, że Shinzo Abe stał się najdłużej pełniącym obowiązki premiera politykiem $\mathrm{w}$ historii Japonii. Niestabilność gabinetów i często zmieniający się szefowie rządów nie 
sprzyjały prowadzeniu odważnej i jednolitej polityki gospodarczej. Chociaż przy władzy od 1955 r. (z krótkimi tylko przerwami) pozostaje jedna partia, to koncepcji na modele gospodarcze było kilka - frakcyjność Partii Liberalno-Demokratycznej i jej liderów blokowała wyklarowanie jednej efektywnej strategii.

Oparta na trzech "strzałach” polityka gabinetu Abe, w swoich założeniach miała być zupełnym przeciwieństwem tego, co na polu gospodarczym czynili poprzednicy z Partii Demokratycznej. Odrzucono model redystrybucji dochodów skierowanej bezpośrednio do gospodarstw domowych na rzecz pobudzenia przedsiębiorczości w celu wykreowania nowych miejsc pracy. Na konferencji 11 stycznia 2013 r. zapowiedział, że rząd będzie zmierzał do osiągnięcia $2 \%$ inflacji, utworzenia 600 tys. nowych miejsc pracy oraz podwyżki wynagrodzeń w kraju (Abenomika 2014). Z zapowiedzi wynikało, że rząd ma zamiar przeznaczyć na pakiet gospodarczy ponad 10 bln jenów, wyłączając z tych szacunków blisko 3 bln na wsparcie programów emerytalnych (Tomaszewski 2020). Finansowy rozmach tego pakietu świadczy o wierze premiera w swój plan - jest to bowiem najkosztowniejszy z pakietów w historii japońskiej gospodarki.

Polityka trzech „strzał” wskazywała główne kierunku rozwoju japońskiej gospodarki na najbliższe lata, stanowiąc podstawę do zmiany całego systemu. Ambasador Japonii w Polsce Makoto Yamanaka w jednym z listów do polskich dyplomatów opisywał, na czym konkretnie polegać ma cały plan nowego gabinetu:

1. Odważna polityka monetarna - ustanowienie $2 \%$ celu inflacyjnego (pierwszy raz w historii Japonii). W celu szybkiego pokonania deflacji należy poluzować politykę monetarną, w ścisłej współpracy rządu z Bankiem Japonii.

2. Elastyczna polityka fiskalna - pobudzanie popytu poprzez pakiet inwestycji publicznych, mających być dźwignią dla japońskiej gospodarki. Elastycznymi ruchami fiskalnymi nazwano chociażby emisję obligacji państwowych.

3. Strategia pobudzenia inwestycji prywatnych i polityka prowzrostowa - w obliczu świadomości, że rząd nie może wiecznie pobudzać gospodarki inwestycjami publicznymi, celem gabinetu miało być stworzenie dobrych warunków do inwestowania i rozwoju prywatnej przedsiębiorczości (List od ambasadora Japonii 2013).

Ponadto rząd założył utworzenie „centrów" sterowania polityką gospodarczą, by zachować jej spójny charakter. Ambasador w liście 
wymienia dwie wiodące instytucje, które miałyby realizować powierzone im zadania:

1. Sztab na rzecz ożywienia gospodarki Japonii - odpowiedzialny za działania mikroekonomiczne i opracowywanie strategii rozwoju, której celem nadrzędnym jest zwiększanie konkurencyjności japońskich przedsiębiorstw i wdrażanie innowacji technicznych.

2. Komisja doradcza do spraw gospodarki i finansów - instytucja odpowiedzialna za politykę makroekonomiczną, zajmująca się długo i średnioterminowymi celami gospodarczo-finansowymi (również reformą systemu podatkowego i przygotowywaniem ustawy budżetowej) (List od ambasadora Japonii 2013).

W japońskiej publicystyce plan budził wiele kontrowersji - zwracano uwagę, że cały ten kosztowny pakiet jedynie pogorszy sytuację finansową kraju i spowoduje wzrost długoterminowych stóp procentowych. Premier Abe zapewniał jednak, że utrzymanie dyscypliny budżetowej jest dla niego priorytetem, a co więcej - dąży do zapewnienia w przyszłym budżecie nadwyżki.

Po stronie opozycji i analityków pojawiały się argumenty, że słaby jen rzeczywiście umocni eksport, ale znacząco osłabi import. Przyjęcie przez parlament całego pakietu stymulacyjnego i wdrażanie „abenomiki” odbierane było jako jasny sygnał, że Japonia będzie od teraz aktywnie uczestniczyć w wojnach walutowych. Polityka obniżki stóp procentowych i zwiększenie roli Banku Japonii w celu skuteczniejszej realizacji planów doprowadziły w pierwszych kwartałach do wzrostu japońskiego eksportu. „Wojnami walutowymi” zwykło określać się sytuację, w której państwo sztucznie obniża wartość swojej waluty w celu zwiększenia siły swojego eksportu. W stosowaniu ostrej polityki walutowej upatruje się sukcesu Chin.

Głównym wyzwaniem (oraz najdroższym) dla rządu miała być realizacja założeń „trzeciej strzały” - głębokich reform strukturalnych, zapewniających Japonii kierunek prorozwojowy: zwiększenie liczby kobiet na rynku pracy, wzrost wynagrodzeń i restrukturyzacja gospodarki. Premier Abe apelował w marcu 2013 r. o zwiększenie płac pracownikom, co poskutkowało jedynie przyznaniem premii na koniec roku obrachunkowego (Stabszy wzrost 2015).

Po wygranych wyborach w grudniu 2014 r. premier Shinzo Abe zapowiedział uruchomienie projektu "Abenomika 2.0”. Ulepszona wersja oryginalnego planu miała być receptą na jeszcze szybszy wzrost gospodarczy i uatrakcyjnienie japońskiej gospodarki w oczach zagranicznych 
inwestorów. Główną obietnicą było obniżenie podatku dla firm oraz utworzenie specjalnych stref ekonomicznych, ułatwiających zakładanie firm przez przedsiębiorców (Mazurczyk 2014).

\section{1 "Abenomika" w praktyce - studium przypadku}

Wygrane wybory w grudniu 2012 r. przez Partię Liberalno-Demokratyczną dały mandat gabinetowi Shinzo Abe do reformowania japońskiej gospodarki. Cała kampania wyborcza skupiona była wokół zmian w konstytucji i spraw poświęconych właśnie ekonomii.

Dnia 22 stycznia 2013 r. premier Abe na wspólnej konferencji prasowej z ówczesnym szefem Banku Japonii ustalili cel inflacyjny, który miał wynosić 2\% (Pitulec 2016: 89). Bank zobowiązał się wtedy do prowadzenia luźniejszej polityki pieniężnej, aby osiągnąć zamierzony cel i zwalczyć panującą deflację. Był to pierwszy raz w historii Japonii, kiedy ustalono cel inflacyjny. Kluczowym działaniem Banku Japonii było zwiększenie ilości pieniądza w obiegu - dwukrotnie w ciągu ok. trzech lat. Od początku 2013 r. Bank Japonii skupował obligacje państwowe, co miało pobudzić akcje kredytowe banków komercyjnych i tym samym pobudzić także konsumpcję wewnętrzną oraz wywołać inflację. Wedle założeń ilość pieniądza w obiegu miała rocznie zwiększać się o ok. 78 bln jenów (Pitulec 2016: 91-92). Wraz ze wzmożoną emisją pieniądza słabł jen. Sprawiło to, że japońskie produkty stały się bardziej konkurencyjne na światowym rynku, a eksport od początku 2013 r. rósł. Zwiększające się zyski przedsiębiorstw nie przekładały się jednak znacząco na wzrost produkcji. Efektem słabnącej waluty stał się za to coraz droższy import, a co za tym idzie - nastąpiła znacząca obniżka realnych dochodów wśród japońskich gospodarstw domowych. Polityka deprecjacji jena wyraźnie uderzyła w japońską konsumpcję, która była odpowiedzialna za 60\% wytwarzanego PKB (Pitulec 2016: 91-92). Przy malejącym oprocentowaniu oszczędności i słabnącym jenie wskaźniki dynamiki konsumpcji i akumulacji oszczędności spadały, bez szans na odbicie w najbliższej przyszłości.

"Abenomika" przynosiła efekty - 2013 r. zamknięto z 1,5\% wzrostem PKB, na giełdzie nastąpiło ożywienie. Między październikiem 2012 a grudniem 2013 r. indeks Topix wzrósł o 70\%.

W pierwszych kwartale 2014 r. aktywność przedsiębiorców osiągnęła poziom dawno niespotykany w Japonii - wiązało się to ściśle z zapowiedzią podwyżki podatku konsumpcyjnego z 5 do 8\%. Szczególnym 
zainteresowaniem cieszyły się dobra trwałego użytku. Następne kwartały to złe wiadomości dla całej gospodarki, która znowu spowolniła.

Pozornie skuteczna okazała się natomiast polityka prowadzona przez Bank Japonii w zakresie realizacji celu inflacyjnego. Na początku 2014 r. odnotowano inflację na poziomie 2,1\%, liczoną indeksem cen konsumpcyjnych - CPI. Spowolnienie, które nastąpiło zaraz po optymistycznym rozpoczęciu roku, ponownie jednak doprowadziło do redukcji inflacji. Brak spektakularnych efektów wymusiło na prezesie Banku Japonii zwiększenie skali luzowania ilościowego. Szacowano wzrost o $70-75 \%$ PKB, jednocześnie podnosząc poziom skupu długoterminowych rządowych papierów dłużnych z 50 do 80 bln jenów rocznie (Kraj 2014). Pomimo wzrostu cen aktywów, obniżenia cen papierów dłużnych i dalszej deprecjacji jena 2014 r. zamknięto z deflacją na poziomie -0,4\% (Pawnik 2020). Dodatkowym czynnikiem napędzającym deflację była sytuacja cen na rynku ropy naftowej - rekordowo niskie ceny tylko pogarszały sytuację. Założonych celów nie udało się osiągnąć również w 2015 r., a powodem była spadająca dynamika konsumpcji w sektorze prywatnym. W ostatnim kwartale roku konsumpcja spadła o 0,8\%, a eksport ledwie drgnął o 0,1\% (Hugh 2014: 22). Wedle ekonomistów powodem nie była wyłącznie podwyżka podatku konsumpcyjnego w kraju. Głównych błędów szukano $\mathrm{w}$ polityce samego Banku Japonii, zarzucając mu niepowodzenia w obszarze transmisji monetarnej ${ }^{3}$.

Duża rolę w sytuacji gospodarczej odgrywa japoński rynek obligacji. Za jego pośrednictwem rząd finansuje ok. 35\% wszystkich wydatków. W obliczu ciągle malejących wpływów z podatków (stanowiły one ok. 50\% finansowania rządu) rynek obligacji będzie stawał się kluczowym polem do działań dla rządzących. Limit zakupów na otwartym rynku papierów dłużnych podniesiono do poziomu 12 bln jenów miesięcznie - jest to skup niemal 70\% emisji pierwotnej. Wedle szacunków Bank Japonii w perspektywie 10 lat będzie posiadał 50\% wszystkich japońskich obligacji rządowych.

Ważnym krokiem w realizacji polityki gospodarczej było wprowadzenie ujemnego procentowania na poziomie $-0,1 \% \mathrm{w}$ dniu 16 lutego $2016 \mathrm{r}$. Ujemne oprocentowanie ustanowiono dla depozy tów w instytucjach bankowych i finansowych zdeponowanych w banku centralnym. Spenalizowano

3 Mechanizm transmisyjny polityki monetarnej - model objaśniający sposób przenoszenia zmian w polityce monetarnej państwa na poziom zmian produkcji, poziomu zatrudnienia czy dochodu. 
przy tym wypłaty gotówkowe, by zachęcić do większej aktywności na rynku kredytowym i kapitałowym.

W drugim kwartale 2018 r. dynamika wzrostu PKB wyniosła w Japonii $0,5 \%$. W ujęciu rocznym dynamika PKB wyniosła $1 \%$. Analitycy przyczyn wzrostu upatrują w rosnącej konsumpcji, która wzrosła o 0,7\% (Żuławiński 2020). W 2018 r wskaźniki realne okazały się zatem zdecydowanie korzystniejsze od tych przewidywanych - np. dynamika inwestycji wyniosła 1,3\% przy 0,6\% przewidywanego wzrostu. Pomimo ciągłego osłabiania jena rozczarowujący okazuje się bilans handlowy, który bardzo mocno uzależniony jest od sytuacji gospodarczej w Stanach Zjednoczonych. Bliskość obydwu gospodarek odbija się w gospodarczych wskaźnikach (Żuławiński 2020). Polityka Donalda Trumpa, mająca na celu redukcję deficytu $\mathrm{w}$ handlu zagranicznym, zmusiła rząd Japonii do szukania potencjalnych partnerów handlowych w innych częściach świata. Skutkiem było chociażby podpisanie umowy o wolnym handlu z Unią Europejską.

W obliczu obawy przed utratą poparcia politycznego rząd Abe odwlekał kolejny etap podwyżki podatku konsumpcyjnego - z 8 do 10\%. Ostatecznie podwyższono stawkę podatku do 10\% w 2019 r. Eksperci i organizacje międzynarodowe od lat wskazywali na potrzebę dostosowania japońskich podatków do realiów gospodarczych (Tomaszewski 2020). Choć ostatnia podwyżka podatku nie przyniosła oczekiwanych efektów i dużego wzrostu wpływów budżetowych, to organizacje międzynarodowe (Międzynarodowy Fundusz Walutowy i Organizacja Współpracy Gospodarczej i Rozwoju) uważają, że w przyszłości konieczne jest dostosowanie skali podatkowej do co najmniej warunków europejskich (Bobowski 2016: 25) (czyli podatków rzędu kilkunastu lub nawet kilkudziesięciu procent). Reforma fiskalna w Japonii może być sposobem na walkę z ogromnym zadłużeniem.

Działania rządu japońskiego w walce z deflacją na przestrzeni tych kilku lat przyniosły raczej niewielkie sukcesy (w 2014 r. w Japonii odnotowano ponad 2,5\% inflacji). Obecne dane i analizy pokazują jednak, że w zależności od okresu wewnętrzna wartość pieniądza w kraju zmienia się w niewielkim stopniu (w 2017 r. średni poziom inflacji wyniósł ok. 0,4\%) (Rynek dla eksperta 2020). Podobną klęską okazuje się walka z nadmiernym zadłużeniem i próbą reform strukturalnych.

„Womenomics", czyli program mający zaktywizować kobiety na rynku pracy, nie przyniósł oczekiwanych efektów. Co prawda od 2012 r. zwiększyła się liczba pracujących kobiet, w 2019 r. stanowiły 44,4\% całej 
japońskiej siły roboczej, ale była to najczęściej nisko płatna praca w niepełnym wymiarze godzin (w 2019 r. było to 44,2\% ze wszystkich pracujących kobiet). Rząd Japonii prowadzi kampanie zachęcające mężczyzn do brania urlopów ojcowskich, jednak w 2018 r. jedynie 6,2\% z nich zdecydowało się na taki krok. Celem rządu było zwiększenie tego wskaźnika do 13\% w 2020 r. W 2018 r. kobiety stanowiły 11,2\% dyrektorów w firmach prywatnych i zajmowały 17,3\% stanowisk menadżerskich. Pomimo postępów Japonia nadal zajmuje drugą lokatę wśród państw OECD, jeżeli chodzi o nierówności płacowe pomiędzy mężczyznami i kobietami. Według danych za 2019 r. kobiety zarabiały o 22,4\% procent mniej niż ich koledzy na tych samych stanowiskach (Catalyst 2020).

\section{Podsumowanie}

Przedstawiona powyżej analiza japońskiej rzeczywistości gospodarczej wskazuje na brak perspektyw do wyjścia z ciągnącej się już trzecią dekadę stagnacji. Opisywane problemy ekonomiczne nakładają się, ale i bezpośrednio wynikają z pogarszającej się sytuacji demograficznej oraz barier kulturowych w społeczeństwie japońskim. Zwesternizowana Japonia zachowała swoją kulturową odmienność, z tradycyjnym podziałem ról społecznych, pozycją ludzi starszych w strukturze społecznej i etosem pracy.

Nadzieja pokładana w Shinzo Abe i „abenomice” okazała się płonna. Potężne transfery pieniężne wpuszczone do gospodarczego krwiobiegu były skuteczne jedynie przez krótki moment. Początkowa poprawa sytuacji ekonomicznej dawała nadzieję na zakończenie trwającej latami stagnacji. W ciągu kolejnych kwartałów zaczęła jednak rosnąć świadomość niedopasowania prowadzonej polityki do sytuacji. Przedsiębiorstwa japońskie coraz rzadziej podnosiły wolumen produkcji, coraz chętniej podnosząc ceny. Realne dochody zwykłych Japończyków stanęły w miejscu, by potem poszybować w dół (po podwyżce podatku konsumpcyjnego). Japonia stała się dobrym przykładem na neoklasyczną teorię neutralności pieniądza w długim okresie, która mówi, że zwiększenie podaży pieniądza nie powoduje zmiany wielkości realnych.

Krótkotrwały efekt pobudzenia gospodarki uśpił rządzących, którzy odkładali w czasie zmiany strukturalne. Na efekty tych reform należałoby 
czekać dłużej, co nie służyło politycznej pozycji premiera i gabinetu. Deregulacja i ułatwienia systemowe dla przedsiębiorców mogłyby okazać się zbawienne w skutkach - dające nadzieję na rzeczywiste pchnięcie gospodarki do przodu na fali stymulacji popytowej. Zachowanie stałego wzrostu, a nie krótkotrwała stymulacja powinno być nadrzędnym celem rządu.

Premier Shinzo Abe 28 sierpnia 2020 r. ogłosił decyzję o rezygnacji ze stanowiska premiera. Powodem był pogarszający się stan zdrowia. Następcą został jego wieloletni współpracownik, główny sekretarz gabinetu premiera, Yoshihide Suga. Zapowiedział on kontynuowanie założeń „abenomiki”, w szczególności skupiając się na strukturalnych reformach gospodarki. Obecnie Japonia zmaga się ze skutkami pandemii koronawirusa i polityka gospodarcza kraju oparta jest na bieżącym reagowaniu na zmieniającą się sytuację epidemiczną. Obserwatorzy japońskiej sceny politycznej twierdzą, że kadencja nowego premiera w rzeczywistości ubiegnie pod hasłem „abenomika minus Yasukuni”. Nowy szef rządu ma bowiem mniej nacjonalistyczne poglądy, $\mathrm{z}$ drugiej zaś strony jest jednym z architektów „abenomiki”.

Hipoteza przyjęta w opracowaniu została zweryfikowana pozytywnie. Powyższa analiza jednoznacznie wskazuje, że realizowanie celów $\mathrm{w}$ ramach polityki monetarnej i fiskalnej nie jest wystarczające, a najważniejszymi czynnikami mogącymi trwale uzdrowić japońską gospodarkę są reformy strukturalne. Zmiany strukturalne dokonane podczas kadencji premiera Abe były niewystarczające. Podstawowym błędem stało się unikanie rozwiązań na poziomie legislacyjnym (co motywowane było kalkulacją polityczną i obawą o utratę elektoratu skupionego wokół japońskich konglomeratów) i ograniczanie się do rekomendacji.

\section{Bibliografia}

Abenomika - japoński program gospodarczy (2014), http://www.argumenty. net/1437 (1.12.2020).

Buzan, B. (1983), People, States and Fear: An Agenda for International Security Studies in Post Cold War Era, (Bringhton: Wheatsheaf Books).

Catalyst (2020), Women in the Workforce - Japan: Quick Take, https:/ / www.catalyst .org/research/women-in-the-workforce-japan/ (4.01.2021). 
Gerlach, M. (1992), Alliance Capitalism: The Social of Japanese Business, (Berkeley: University of California Press).

Grabowiecki, J. (2000), Japonia. Powojenna dynamika i równowaga gospodarcza, (Warszawa: Szkoła Główna Handlowa).

Grabowiecki, J. (2005), Przyczyny stagnacji gospodarczej Japonii, „Gospodarka Narodowa" 5/6: 66-70.

Kiermacz, W. (2018), Japoński system emerytalny czyli uczmy się na cudzych błędach, https:/ / www.analizy.pl/fundusze/wiadomosci/23667/japonski-system-emerytalny-czyli-uczmy-sie-na-cudzych-bledach.html\#_ftnref7 (17.12.2020).

Kraj, M. (2014), Połowiczne sukcesy Abenomiki, https:/ / finanse.wp.pl/polowiczne-sukcesy-abenomiki-6114853233624705a (1.12.2020).

Kruczkowska, M. (2019), Wesołe życie japońskiego staruszka za kratami. W ciągu dwóch dekad liczba "najstarszych" przestępców wzrosła czterokrotnie, http:/ / wyborcza.pl/7,75399,24442500,wesole-zycie-japonskiego-staruszka-za-kratami-w-ciagu-dwoch.html (1.12.2020).

Księżopolski, K. M. (2011), Bezpieczeństwo ekonomiczne, (Warszawa: Dom Wydawniczy „Elipsa”).

List od ambasadora Japonii w Polsce (2013), https:/ /jaap.pja.edu.pl/list-od-ambasadora-japonii-w-polsce/ (1.12.2020).

Marszałek-Kawa J., T. Bodio (red.) (2017), Japońskie realia. Polityka i gospodarka, (Torun: Wydawnictwo Adam Marszałek).

Mazurczyk, A. (2014), Japonia: Partia Liberalno-Demokratyczna wygrywa wybory. Abenomika dziata?, https://www.polityka.pl/tygodnikpolityka/ swiat/1602893,1,japonia-partia-liberalno-demokratyczna-wygrywa-wybory-abenomika-dziala.read (1.12.2020).

Michałowski, S. (1990), Bezpieczeństwo ekonomiczne w stosunkach Wschód-Zachód, (Warszawa: PISM).

Młodawska, J. (1999), Japonia. Państwo a sektor prywatny, (Warszawa: Wydawnictwo Naukowe PWN).

Młodawska, J. (2003), Kryzys systemu bankowego i finansowego w Japonii - drogi wyjścia, „Bank i Kredyt” 7: 60.

Mrowiec, M. (2017), Austriacka Szkoła Ekonomii. Jak może pomóc wyjaśnić stagnacje gospodarki Japonii, (Warszawa: Wydawnictwo Naukowe PWN).

Pawnik, A., Bank Japonii - historia, zasady działania, rola prezesa, http:/ / pulsazji.pl/ 2018/02/28/bank-japonii (1.12.2020).

Perczyński, M. (1990), Globalne uwarunkowania bezpieczeństwa ekonomicznego, (Warszawa: PISM).

Pieliński, B. (2012), Polityka społeczna wobec starzejącego się społeczeństwa. Rozwój systemu emerytalnego i Ubezpieczenia Opieki Długoterminowej w Japonii, „Problemy Polityki Społecznej" 18: 6. 
Pitulec, D. (red.) (2016), Wolny handel i szybki rozwój. Wspótczesne priorytety w gospodarce światowej, (Wrocław: Wydawnictwo Uniwersytetu Ekonomicznego).

Potocka, E., M. Pietrasiak (red) (2004), Wspótczesna Japonia: mocarstwo na rozdrożu, (Łódź: Wydawnictwo Uniwersytetu Łódzkiego).

Stabszy wzrost w Japonii pod wptywem wyzwan demograficznych (2015), http://global.beyondbullsandbears.com/pl/2015/12/01/slabszy-wzrost-w-japonii-pod-wplywem-wyzwan-demograficznych/ (1.12.2020).

Sperling, J., E. Kirchner (1998), Economic Security and the Problem of Cooperation in Post-Cold War Europe, „Review of International Studies” 24: 221-237.

The Asahi Shimbun, http://www.asahi.com/ajw/.

The Japan Times, https://www.japantimes.co.jp/.

Tomaszewski, W., Cztery problemy Japonii, http://www.polska-azja.pl/w-tomaszewski-cztery-problemy-japonii/ (1.12.2020).

Wydział Promocji Handlu i Inwestycji Ambasady RP w Tokio na podstawie „The Japan Times", z dnia 17 i 29 grudnia 2014 roku, https:/ /japan.trade.gov.pl/ $\mathrm{pl} /(1.12 .2020)$

Ząbkowicz, A. (2007), Instytucje i wzrost gospodarki Japonii, (Kraków: Wydawnictwo Uniwersytetu Jagiellońskiego).

Źródła i dane Banku Światowego, http:/ /www.worldbank.org/.

Źródła i dane Międzynarodowego Funduszu Walutowego, https:/ /www.imf.org/.

Źródła i dane Światowej Organizacji Handlu, https:/ / www.wto.org/. 